\title{
Relationship Between Physiological Characteristic and Bean Quality on Some Cocoa (Theobroma cacao L.) Clones
}

\author{
Indah Anita-Sari ${ }^{* *}$, Fakhrusy Zakariyya ${ }^{1)}$, and Agung Wahyu Susilo ${ }^{1)}$ \\ ${ }^{1)}$ Indonesian Coffee and Cocoa Research Institute, J1. PB. Sudirman 90, Jember Indonesia \\ ${ }^{*}$ Corresponding author: indah.sari83@yahoo.com \\ Received: 24 June 2015 / accepted: 16 August 2015
}

\begin{abstract}
Photosynthesis is one of the physiological processes that influences bean quality and this process related with the effectiveness of the stomata characters and chlorophyll content in leaves. The research was aimed to study the relationship between some physiological characteristics and bean quality on some cocoa (Theobroma cacao L.) clones. The research was conducted at Kaliwining Research Station, Indonesian Coffee and Cocoa Research Institute. Design of experiment was randomized complete block design consisted of six clones as treatment were Sulawesi 01, Sulawesi 02, Sca 6, ICS 60, TSH 858, ICCRI 03, PA 300. Each treatment was replicated three times. Stomata diffusion resistance, transpiration, content of chlorophyll $a$, chlorophyll $b$, chlorophyll total $(a+b)$, bean number and bean weight were observed. The results of experiment showed that difference in chlorophyll $a$, chlorophyll $b$, chlorophyll total $(a+b)$, stomata diffusion resistance, bean number and bean weight were found in the six clones tested. Transpiration rate was not significantly different between those clones. Sulawesi 01 showed the highest content of chlorophyll $a$ and ICS 60 and ICCRI 03 showed higher content of chlorophyll $b$ than the other clones. Chlorophyll $a, b$ and total $(a+b)$ showed positively influence on bean number and bean weight. Transpiration rate had negatively influence on bean number per pod, on the otherhand, it showed positively influence to bean weight. Chlorophyll total $(a+b)$ showed high genetic variance, high phenotypic variance and high estimated value of heritability. The chlorophyll $a$ and $b$ had moderate genetic variance, moderate phenotypic variance and high of estimated value of heritability. Chlorophyll total $(a+b)$ could be used as a selection criteria based on the value of correlation, genetic variance, phenotypic variance and estimated value of heritability which would give high opportunity in selection process.
\end{abstract}

Keywords: early detection, physiological characteristic, bean weight, Theobroma cocoa L.

\section{INTRODUCTION}

Bean quality is one important aspect to consider in development of cocoa planting materials. According to Indonesion National Standard (SNI: Standar Nasional Indonesia), dry bean weight is one of the parameter which was used to determine the bean quality. Bean weight reflects genetic expression of the environment. Physiological characters influence the photosynthesis process to produce the biomass in plants, therefore it can be used as a selection indicator for bean weight produced by a genotype. In conventional breeding, physiological character can be used as selection indicator (Gollojeh \& Ranjbar, 2012).

Photosynthesis is related with the effectiveness of stomata and chlorophyll content 
in the leaf mesophyll. Experiment results on rice showed that chlorophyll influenced biomass production (Hassan, 2009). The high content of chlorophyll $a$ and $b$ in a genotype related with the high capacity in biomass accumulation and photosynthesis rate. Hassan et al. (2009) reported that there were differences of chlorophyll content in the rice plants.

The characteristics of stomata influenced $\mathrm{CO}_{2}$ fixation in the leaf mesophyll (Wong et al., 1979). The content of $\mathrm{CO}_{2}$ increased photosynthesis rate and stomata diffusion resistance on otherhand it decreased the stomata conductance. Stomata diffusion resistance influences gas $\left(\mathrm{CO}_{2}\right)$ exchange and transpiration (water loss) through stomata. High stomata diffusion resistance will cause decrease in transpiration (Adisyahputra, 2011), and it has a role in maintaining water status in plants. This process was influenced by the stomata aperture (Solangi et al., 2012). The stomata conductance and assimilation rate of $\mathrm{CO}_{2}$ on $\mathrm{C} 3$ species depend on solar radiation and leaf temperature (Ancu et al., 2014). Plants response to $\mathrm{CO}_{2}$ content is carried out by increasing photosynthesis and reducing stomata conductance (Elizabeth et al., 2007). Stomata conductance value is influenced by stomata density, stomata size and stomata aperture (Evans, 1983).

Transpiration is water loss process from the plants to atmosphere in vapor form. Not all water content in plants is used in photosynthesis process, but water excess will be removed through transpiration. High level of transpation can affect the plants when losing water too much. Transpiration is an important physilogical process that is very dinamic, regulated mechanism and adaptated to internal and external condition, mainly when assosiated with cell turgidity, absorption and water transport (Al \& Ratnawati, 2004). Identification of chlorophyll content, stomata diffusion resistance and transpiration rate on some cocoa clones can be used to estimate the photosynthesis rate and yield in each clone. The research was aimed to study the relationship between physiological characters and bean quality on some cocoa clones.

\section{MATERIALS AND METHODS}

The research was conducted at Kaliwining Research Station, Indonesian Coffee and Cocoa Research Institute $(45 \mathrm{~m}$ above sea level, climate type D according to the classification of Schmidt \& Ferguson). Design of experiment was randomized complete block design consisted of six clones as treatment. The selection of clones based on bean size; small (Sca 6), medium (Sulawesi 01, Sulawesi 02, PA 300) and large (TSH 858, ICS 60). The plants used for this experiment were derived from 10 years old top grafting. Plant maintenance in accordance with the standards of cocoa cultivation at ICCRI with the spacing of $3 \mathrm{~m} \times 3 \mathrm{~m}$ and using lamtoro (Leucaena spp.) for permanent shading. Each treatment was replicated three times. Each plot consisted of 10 sample trees. The parameters observed were stomata diffusion resistance, transpiration, the content of chlorophyll $a$, chlorophyll $b$, chlorophyll total $(a+b)$, bean number and bean weight. Stomata diffusion resistance was measured by using a steady state porometer (LI-1600, Licor incorporation, USA). During the gas exchange measurements leaf chamber temperatures was $29.5-30.1^{\circ} \mathrm{C}$. Chlorophyll content was observed by measuring according to Arnon (1949). Leaves were taken from young fully-expanded ones in amount of $2 \mathrm{~g}$ of fresh leaves. Thus, sample was blended with $50 \mathrm{~mL}$ of $80 \%$ acetone. Subsequently, it was poured into an erlenmeyer and diluted until $100 \mathrm{~mL}$ with acetone. It was taken as much as $5 \mathrm{~mL}$ and poured untill $50 \mathrm{~mL}$ by 
using acetone then measured using spectrophotometer. The absorbance of chlorophyll $a$ was measured on $645 \mathrm{~nm}$ and the absorbance of chlorophyll $b$ was measured on $663 \mathrm{~nm}$. Bean number was observed by counting the beans from 10 pod samples and bean weight observed by measuring the sun dried bean from 10 pod samples. The data was analyzed with SAS 9.1 programme and Excell 2010 programmes. Genetic variance, phenotypic variance and estimated value of heritability were analyzed using excell programme based on Singh \& Chaudary (1979) method. Variance analysis was done by $\mathrm{F}$ test and the significantly analysis used Duncan test with 5\% level. Genetic variance, phenotypic variance, and estimated value of heritability was analyzed based on variance analysis. Genotypic variance was classified according to Knight (1979) and phenotypic variance was classified according to Qosim et al. (2000). Classification of heritability value was based on Mc. Whiter (1979).

\section{RESULTS AND DISCUSSION}

Variance analysis showed that there were differences in chlorophylla $a$, chlorophyll $b$, chlorophyll total $(a+b)$, stomata diffusion resistance, bean number and bean weight between the six cocoa clones tested. Transpiration rate did not show significantly different between the six clones tested (Table 1).
Sulawesi 01 showed the highest chlorophyll $a$ content compared to other clones (Table 2). ICS 60 and ICCRI 03 had higher chlorophyll $b$ than the others. Meanwhile, PA 300 showed the lowest total chlorophyll $(a+b)$. Ritchie (2008) reported that chlorophyll $a$ is generally used as basis to measure photosynthesis and transpiration rate in the plants. Chlorophyll $a, b$ and total $(a+b)$ had a principal function in receiving and storage process of light energy by resonant induction (Candan \& Tarhan, 2003). Chlorophyll and carotenoid content associated with photosynthesis potential and provide the plant physiological status indicator (Gamon \& Surfus, 1999). The high content of chlorophyll $a$ and $b$ will have high potential of biomass production (Suharja \& Sutarno, 2009). In addition the content of chlorophyll had relationship with aging process (Brown et al., 1991). Ai \& Banyo (2011) reported that each species had different chlorophyll content. The content of chlorophyll $a$ and $b$ in Sulawesi 01, ICS 60, and ICCRI 03 was higher than Sca 6 while bean weight character in Sulawesi 01, ICS 60, and ICCRI 03 was bigger and significantly different than Sca 6. Biomass differences can result in differences in seed mass and emergence time (Van Andel \& Biere, 1990).

Transpiration rate was not significantly different between the six cocoa clones tested, while stomata diffusion resistance was significantly different between six cocoa

Table 1. Variance analysis of bean weight, bean number, chlorophyll total $(a+b)$, chlorophyll $a$, chlorophyll $b$, stomata diffusion resistance, transpiration rate on some cocoa clones

\begin{tabular}{lcccccccc}
\hline Source & df & $\begin{array}{c}\text { Bean } \\
\text { weight }\end{array}$ & $\begin{array}{c}\text { Bean } \\
\text { number }\end{array}$ & $\begin{array}{c}\text { Chlo } \\
\text { total }\end{array}$ & Chl $a$ & Chl $b$ & $\begin{array}{c}\text { Stomata } \\
\text { diffusions } \\
\text { resistance }\end{array}$ & Transpiration \\
\hline Genotype & 5 & $0.240 *$ & $37.16 *$ & $36.50 *$ & $15.42 *$ & $8.34 *$ & $0.120 *$ & 0.018 ns \\
Block & 2 & 0.054 & 45.50 & 5.11 & 18.11 & 0.11 & 0.005 & 0.010 \\
Error & 10 & 0.017 & 52.16 & 25.60 & 8.44 & 5.85 & 0.013 & 0.030 \\
\hline Note: ${ }^{*}$ is significant on $1 \%$ test level. & & & & &
\end{tabular}


clones (Table 2). The stomatal transpiration and resistant levels were related with spesies or plant variety (Sena et al., 2007). ICS 60 showed the highest transpiration rate but it was not significantly different with others. According to Baligar et al. (2010), there was not significantly different of transpiration rate on three cocoa seedling populations. Sca 6 showed the highest stomata diffusion resistance, on other hand ICS 60 showed the lowest stomata resistance diffusion. Stomata resistance diffusion will influence gas $\left(\mathrm{CO}_{2}\right)$ exchange and transpiration (water loss) through stomata.

High stomata diffusion resistance will cause increase in transpiration (Adisyahputra, 2011), and it has a role in maintaining the water status in the plants. This process was influenced by the stomata aperture (Solangi et al., 2012). The high content of $\mathrm{CO}_{2}$ in the leaves will cause increasing of stomata diffusion resistance. If the content of $\mathrm{CO}_{2}$ in the leaves increase it will decrease stomata conductance and stomata will be closed. The high stomata diffusion resistance decrease transpiration rate, so the water content in leaves can be used for photosynthesis process. Based on Pratama (2009), the level aperture of stomata was important factor which influence stomata diffusion resistance. A low stomata conductance increased leaf temperature which influenced transpiration rate through leaf surface. The level of stomata conductance would allow the high of photosynthesis and transpiration potential (Daymond et al., 2011). Photosynthesis process on their own was not always associated with yield, because the photosynthesis rate in the leaves would be influenced by the plant canopy and biomass (Daymond et al., 2011).

The resuts of experiment showed that difference in bean number and bean weight characters in the six cocoa clones tested (Table 2). Sulawesi 01 and PA 300 had higher bean number per pod than other clones. Bean weight character of ICS 60 and Sulawesi 02 showed larger than other clones. Sca 6 showed the smallest of bean weight. Bean weight character was influenced by genetic and environmental factors. Bean weight reflects assimilates produced during photosynthesis.

Table 2. Chlorophyll $a, b,(a+b)$, transpiration rate, stomata diffusion resistance, bean number and bean weight on some cocoa clones

\begin{tabular}{|c|c|c|c|c|c|c|c|}
\hline & Chl $a$ & Chl $b$ & \multirow{2}{*}{$\begin{array}{l}\text { Chl } a+b \\
\mu \mathrm{mol} / \mathrm{g}\end{array}$} & \multirow{2}{*}{$\begin{array}{l}\text { Transpiration } \\
\text { rate } \mu \mathrm{g} \mathrm{cm}^{2} / \mathrm{s}\end{array}$} & \multirow{2}{*}{$\begin{array}{l}\text { Stomatals } \\
\text { diffusion } \\
\text { resistance/cm }\end{array}$} & \multirow{2}{*}{ Bean number } & \multirow{2}{*}{$\begin{array}{c}\text { Bean weight } \\
(\mathrm{g})\end{array}$} \\
\hline & \multicolumn{2}{|c|}{$\mu \mathrm{mol} / \mathrm{g}$} & & & & & \\
\hline Sulawesi 01 & $10.79 \mathrm{a}$ & $4.03 \mathrm{ab}$ & $14.823 \mathrm{a}$ & $2.27 \mathrm{a}$ & $2.21 \mathrm{ab}$ & $44.0 \mathrm{a}$ & $0.69 \mathrm{ab}$ \\
\hline ICS 60 & $10.27 \mathrm{ab}$ & $5.25 \mathrm{a}$ & $15.533 \mathrm{a}$ & $2.37 \mathrm{a}$ & $1.87 \mathrm{~d}$ & $35.7 \mathrm{ab}$ & $1.02 \mathrm{a}$ \\
\hline Sca 6 & $8.11 \mathrm{ab}$ & $3.98 \mathrm{ab}$ & $12.097 \mathrm{a}$ & $2.18 \mathrm{a}$ & $2.42 \mathrm{a}$ & $36.3 \mathrm{ab}$ & $0.24 \mathrm{~b}$ \\
\hline ICCRI 03 & $7.84 \mathrm{ab}$ & $6.71 \mathrm{a}$ & $14.623 \mathrm{a}$ & $2.15 \mathrm{a}$ & $2.31 \mathrm{ab}$ & $35.3 \mathrm{ab}$ & $0.69 \mathrm{ab}$ \\
\hline Sulawesi 02 & $6.22 \mathrm{ab}$ & $3.18 \mathrm{ab}$ & $9.400 \mathrm{ab}$ & $2.19 \mathrm{a}$ & $2.01 \mathrm{dc}$ & $36.7 \mathrm{ab}$ & $1.00 \mathrm{a}$ \\
\hline PA 300 & $4.91 \mathrm{~b}$ & $1.88 \mathrm{~b}$ & $6.803 \mathrm{ab}$ & $2.28 \mathrm{a}$ & $2.11 \mathrm{ab}$ & $41.0 \mathrm{a}$ & $0.78 \mathrm{ab}$ \\
\hline
\end{tabular}

Note: Numbers within the same column followed by the same letter are not significantly different at $5 \%$ level according to Duncan test. 
The results of correlation analysis showed that content of chlorophyll $a$, chlorophyll $b$, and chlorophyll total $(a+b)$ had significantly different correlation to bean number and bean weight (Table 3). Mayor et al. (2007) showed that chlorophyll content had positively correlation with productivity within and across species on Picea rubens, Picea mariana and their hybrid. Chlorophyll pigment content traits had been positively correlated with net photosynthesis, productivity, but it is clear that the genetic correlation among photosynthesis, growth and chlorophyll content can be complicated and depend on many factors.

Chlorophyll is a pigment that have function in photosynthesis process and it influences assimilate production in plants. Chlorophyll $a$ is dark green color and chlorophyll $b$ is green color and both of them were strong in absorbing red light (Ai \& Banyo, 2011). The correlation analysis showed that chlorophyll $a$ had positive relationship between chlorophyll $b$ and chlorophyll total. These results were similar with Lobato et al. (2009), that there was a significant and positive relationship between chlorophyll $a$ and chlorophyll total in Capsicum anuum. Chlorophyll is the main component in chloroplast that support photosynthesis process (Li et al., 2006) and related with this experiment results the content of chlorophyll $a, b$ and total $(a+b)$ had positively correlation with bean number and bean weight which reflected assimilate production. In Capsicum annum showed the positive correlation between chlorophyll a and total soluble carbohydrates (Lobato et al., 2009). In spinach, chlorophyll $a$ and $b$ were all similar using various formulae in $90 \%$ acetone, methanol and ethanol (Ritchie et al., 2008).

Transpiration rate showed negatively correlation with bean number, but had positively correlation with bean weight (Table 3 ). Transpiration is water loss process in vapor form from plant and mostly through stomata (Ai \& Ratnawati, 2004). Transpiration rate was influenced by stomata aperture and stomata diffusion resistance.

Stomata diffusion resistance increases greatly with the reduction of pore opening (Sena et al., 2007). A highly significant positive correlation between stomatal conductance and grain yield was found on wheat. The

Table 3. Correlation analysis of cholophyll content, bean number, bean weight, transpiration and stomatal diffusion resistance

\begin{tabular}{|c|c|c|c|c|c|c|c|}
\hline & Chl $a$ & Chl $b$ & Chl total & Bean number & Bean weight & Transpiration & $\begin{array}{l}\text { Stomata } \\
\text { resistance }\end{array}$ \\
\hline Chl $a$ & & $0,69^{*}$ & $0,94^{*}$ & 0,30 ns & 0,14 ns & $-0,14 \mathrm{~ns}$ & $-0,09$ ns \\
\hline Chl $b$ & & & $0,90^{*}$ & $0,16^{\mathrm{ns}}$ & 0,10 ns & $-0,26^{\mathrm{ns}}$ & $-0,02$ ns \\
\hline Chl tot & & & & 0,26 ns & 0,14 ns & $-0,21 \mathrm{~ns}$ & $-0,07$ ns \\
\hline Bean number & & & & & $-0,11 \mathrm{~ns}$ & $-0,05 \mathrm{~ns}$ & 0,05 ns \\
\hline Bean weight & & & & & & 0,07 ns & $-0,40 \mathrm{~ns}$ \\
\hline Transpiration & & & & & & & $-0,40 \mathrm{~ns}$ \\
\hline Stomata resistance & & & & & & & \\
\hline
\end{tabular}



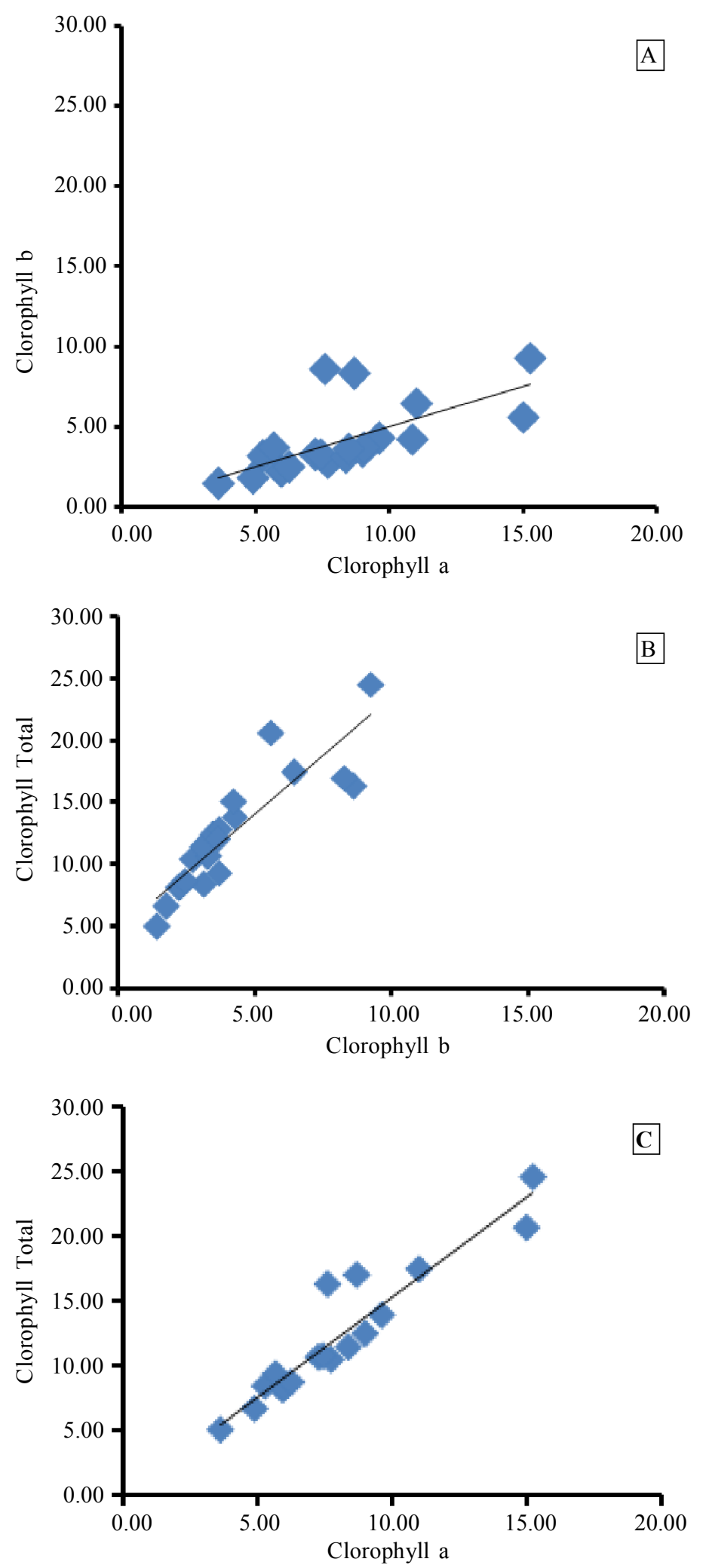

Figure 1. Relationship between chlorophyll $a$ and chlorophyll $b$ (A); chlorophyll $b$ and chlorophyll total $(a+b)(\mathrm{B})$; and chlorophyll $a$ and chlorophyll total $(a+b)(\mathrm{C})$ 
positive correlation between stomata conductance and grain yield was to be expected considering that this variable is closely linked to the photosynthetic rate (Delgado et al., 1994). High transpiration occured when low stomata diffusion resistance and it caused high water loss from the leaves. Water is one of the photosynthesis compounds, so that high water loss from the leaves will reduce the raw materials $\left(\mathrm{H}_{2} \mathrm{O}\right)$ and it will decrease the photosynthesis rate. Sane et al. (2007) reported that water deficit can reduce the photosynthesis level from $53-64 \%$, that the decline was due to stomatal closure.

Chlorophyll total $(a+b)$ had high genotypic variance $\left(\sigma_{\mathrm{g}}^{2}\right)$, high phenotypic variance $\left(\sigma_{\mathrm{f}}^{2}\right)$ and high estimated value of heritability (H). Chlorophyll $a$ and $b$ showed moderate genotypic variance $\left(\sigma_{\mathrm{g}}^{2}\right)$, moderate phenotypic variance $\left(\sigma_{\mathrm{f}}^{2}\right)$ and high estimated value of heritability $(\mathrm{H})$. Based on the analysis result, chlorophyll total $(a+b)$ could be used as a selection criteria because this charac- ter had high genotypic variance, high phenotypic variance and high estimated value of heritability and positively correlation with bean weight and it would give high opportunity in selection process. Genetic influence on physiological characteristic range from single gene effects (Kiddy, 1979). The high value of heritability and genotypic variance determine the selection process. The high value of genotypic variance show the opportunity to effective remedial efforts through selection (Boer \& Wijayanto, 2012). Genetic parameter value can be used as a basis for selection program in quantitative character without ignoring the population median value. Assessment of low or high variance in population is based on genetic variant coefficient.

\section{CONCLUSION}

Chlorophyll content and stomatal diffusion resistance as physiological characteristics in leaves influenced the bean weight and showed

Table 4. Genotype variance, phenotype variance and heritability on some physilogical characters

\begin{tabular}{lccc}
\hline Character & Genotype variance & Phenotype variance & Heritability, \% \\
\hline Chlorophyll total $(a+b)$ & 27.97 & 36.50 & 76.62 \\
Chlorophyll $a$ & 12.61 & 15.42 & 81.76 \\
Chlorophyll $b$ & 6.39 & 8.34 & 76.62 \\
Stomata diffusion resistance & 0.12 & 0.12 & 96.39 \\
Transpiration & 0.01 & 0.02 & 44.44 \\
\hline
\end{tabular}


the significantly different in the six cocoa clones. The relationship between physiological characteristics and cocoa bean quality was to be expected considering that this variable is closely linked to the photosynthetic rate.

\section{DAFTAR PUSTAKA}

Adisyahputra; Sudarsono \& K. Setiawan (2011). Pewarisan sifat densitas stomata dan laju kehilangan air daun kacang tanah. Jurnal Natur Indonesia, 14, 73-89.

Ai, N.S. \& Y. Banyo(2011). Konsentrasi klorofil daun sebagai indikator kekurangan air pada tanaman. Jurnal Ilmiah Sains, 11, 166-173.

Ai, S. \& Ratnawati (2004). Respons konduktansi stomata dan laju transpirasi rumput blembem (Ischaemum ciliare, Retzius) di sekitar sumber emisi gas kawah Sikidang, Dieng. Prosiding Penelitian, Pendidikan dan Penerapan MIPA. FMIP Universitas Negeri Yogyakarta, 2 Agustus.

Ancu, S.; E. Chitu; F.C. Marin, I. Ancu; C. Plopa (2014). Correlation of stomatal conductance with photosynthetic capacity of six walnut cultivars from the national assortment. South Western Journal of Horticulture Biology and Environment, 5, 1-10.

Baligar, V.C.; N.K. Fageria; J.A. Bunce, M.K. Elson (2010). Irradiance, external carbon dioxide concentration and temperature influence photosynthesis in tropical cover crop legumes. Tropical Grasslands, 44, 24-32.

Boer, D. \& T. Wijayanto (2012). Analisis variabilitas genetik dan heritabilitas berbagai karakter agronomi 30 kultivar jagung (Zea Mays L.) lokal Sulawesi Tenggara. Penelitian Agronomi, 1, 174-183.

Brown, S.B.; J.D. Houghton \& G.A.F. Hendry (1991). Chlorophyll break down. 465-489. In: H. Scheer (Ed.), Chlorophylls, CRC Press, Boca Raton, FL.

Candan, N.L. \& Tarhan (2003). The correlation between antioxidant enzyme activities and lipid peroxidation levels in Mentha pulegium organs grown in $\mathrm{Ca}^{2+}, \mathrm{Mg}^{2+}$, $\mathrm{Cu}^{2+}, \mathrm{Zn}^{2+}$ and $\mathrm{Mn}^{2+}$ stress conditions. Plant Science, 163, 769-779.

Daymond, A.J.; P. J. Triker \& P. Hadley (2011). Genotypic variation in photosynthesis in cacao is correlated with stomatal conductance and leaf nitrogen. Biologia Plantarum, 55, 99-104.

Delgado, M.I.; M.P. Reynolds; A.L. Saavedra \& T. Nava (1994). Genetic Diversity for Photosynthesis in Wheat under Heatstressed Environments and Its Relationship to Productivity. CIMMYT.

Elizabeth, A.; Ainsworth \& A. Roger (2007). The response of photosynthesis and stomatal conductance to rising $(\mathrm{CO} 2)$ : mechanisms and environmental interactions. Plant, Cell and Environtment, 30, 258-270.

Evans, J.R. (1983). Nitrogen and photosynthesis in the flag leaf of wheat (Triticum aestivum L.). Plant Physiology, 72, 297-302.

Gamon, J.A. \& J.S. Surfus (1999). Assessing leaf pigment content and activity with a reflectometer. New Phytologist, 143, 105-117.

Hassan , M.S.; A. Khair; M.M. Haque; A.K. Azad \& A. Hamid (2009). Genotypic variation in traditional rice varieties for chlorophyll content, SPAD value and nitrogen use efficiency. Bangladesh Journal Agriculture Research, 34, $505-515$.

Kiddy, C.A. (1979). A review of research on genetic variation in physiological characteristics related to performance in dairy catle. Journal Dairy Science, $62,18-24$.

Knight, R. (1979). Quantitative sstatistics and plant breeding. In: R. Knight (ed) Plant Breeding. Brisbane, Australia.

Li, R.; P. Guo; M. Baum; S. Grando; S. Ceccarelli (2006). Evaluation of chlorophyll content and fluorescence parameters as indicators of drought tolerance in barley. Agricultural Sciences in China, 5, 751-757. 
Lobato, A.K.S.; L.M. Luz; R.C.L. Costa; \& Tan (2009). Relationship between chlorophyll a and total solube carbohydrates in pepper submitted to water deficiency. Journal of Animal \& Plant Science, 5, 515-526.

Mayor, J.E.; D.C. BArsi; A. Mosseler \& M. Campbell (2007). Genetic variation and control of chloroplast pigment concentration in Picea rubens, Picea mariana and their hybrids impact of elevated (CO2) environtments. Tree Physiology, 353-364

McWhirter, K.S. (1979). Breeding of cross polination crop. 79-111. In: R. Knight (Ed.). Plant Breeding, Brisbance Australian Vicc-chancellors Committee.

Qosim, W.A.; A. Karuniawan; B. Marwoto \& D.S. Badriah (2000). Stabilitas parameter genetik mutan-mutan krisan generasi VM3. Laporan Hasil Penelitian Lembaga Penelitian Universitas Padjajaran. Jatinangor.

Ritchie, R.J. (2008). Universal chlorophyll equations for estimating chlorophyll a, b, c, and d and total chlorophylls in natural assemblages of photosynthetic organisms using acetone, methanol, or ethanol solvents. Photosynthetica, 46, 115-126.
Sena, J.O.A.; H.A. Zaidan \& P.R.d.C. Castro(2007). Transpiration and stomatal resistance variations of perennial tropical crops under soil water availability conditions and water deficit. Brazilian Archives of Biology and Technology an International Journal, 50, 225-230.

Solangi, G.S.; M.K. Lohar; G.H. Abro \& A.S. Buriro (2012). Biology and release of exotic predator Cryptolaemus montrouzieri Mulsant on mealbug Phenococcus solenopsis Tinsley at Tandojam. Sarhad Journal Agriculture, 28, 429-435.

Suharja \& Sutarno (2009). Biomass, chlorophyll and nitrogen content of leaves of two chili pepper varieties (Capsicum annum) in different fertilization treatments. Bioscience, 1, 9-16.

Van Andel, J. \& A. Biere (1990). Ecological Significance of Variability in Growth Rate and Plant Productivity. SPB Academic Publishing. The Hague, the Netherlands, 257-268.

Wong, S.C.; R. Cowan \& G.D. Farquhar (1979). Stomata conductance correlates with photosynthetic capacity. Nature, 282, $424-426$.

$* * 0 * *$ 